\title{
A REVIEW STUDY ON BIOCOMPATIBLE IMPROVEMENTS OF NITI-BASED SHAPE MEMORY ALLOYS
}

\author{
Safar Saeed Mohammed ${ }^{* 1}$ (D), Mediha Kök ${ }^{2}$ (D), Ibrahim Nazem Qader ${ }^{\text {(D) }}$,Meltem Coşkun ${ }^{2}$ (D)
}

${ }^{I}$ Department of Physics, College of Science, University of Raparin, Sulaymaneyah, Iraq

${ }^{2}$ Department of Physics, Faculty of Science, Firat University, Elazig, Turke

\section{Abstract}

NiTi-based shape memory alloys (SMAs) have many applications, especially for implantation, however since they are not a passive material so it is important to investigate them from different biocompatible perspectives. In this study, we introduced the important physical characteristics of NiTi alloys, then we explained different biocompatible terminologies, including carcinogenic, genotoxic, cytotoxicity, mutagenic, allergic, and corrosivity. We collected some important previous works that investigated the biocompatibility of NiTi-based SMAs and the different techniques used for improving the alloy and diminishing the hazard due to Ni-leakages.

Keywords: NiTi, shape memory alloys, biocompatibility, toxicity, Carcinogenic, Mutagenic

\section{Introduction}

Smart materials are a group of engineering materials that have many technological applications $[1,2]$, besides, shape memory alloys (SMAs) are a special type of smart materials which are received more attention compared to other types of smart materials because they are able to recover and a deformed shape through some specific mechanisms [3-7]. SMAs have two main phases which are austenite and martensite phases. Austenite is stable at high temperatures while martensite is stable at low temperatures, and the phase transformation from austenite to martensite and vice versa can be obtained through the heating/cooling process [8-20]. Also, the ability of SMAs to return to their previous shape is specified into two different categories, which are shape memory effect (SME) and superelasticity (SE). Because of these interest behaviors, SMAs are widely used in modern technological applications, such as robotics, automotive, aerospace, and medical application [21]. Additionally, some SMAs, especially NiTi-based alloys, are used as biomedical materials. Biocompatibility is an ability of biomedical materials since they are implanting in the human body, so they should be passive and do not damage the living tissues [22]. Besides, the biocompatibility of SMAs is relative, therefore they can be improved by some basic techniques such as heat treatment and alloying process. In the past few decades, many studies in the literature could improve the biocompatibility of SMAs. For example, Jin et al. used a filtered arcing ion plate technique to coating NiTi alloy with the tin element. They reported that $\mathrm{Sn}$ enhanced the biocompatibility of their sample [23]. Likewise, Zhang and coworkers improved the biocompatibility and anticorrosion resistance of a binary NiTi SMA by coating its surface with graphene [24]. Also, Tao and coworkers performed the oxidation treatment on a NiTi SMA using $\mathrm{H}_{2} \mathrm{O}_{2}$ solution, and they stated that the wettability, blood compatibility, and fibroblasts compatibility were improved after coating the sample with a titanium oxide layer [25].

In this article, most studies conducted about improving the biocompatibility of NiTi-based shape memory alloys have been reviewed. Firstly, we discussed the main features of shape memory alloys, then we explained some biocompatible terminology used for biomedical materials. Also, the techniques used to improve and minimize the risks of using these smart materials are highlighted.

\section{General Characteristics of SMAs}

As we mentioned before, SMAs have two main phases which are austenite and martensite. Also, they can be transferred from one phase into the other counterpart, also they able to return to their previous shape only by manipulating temperature. This ability is based on two main characteristics, which are known as SME and SE.

\subsection{Shape Memory Effect (SME)}

When the SMA phase is converted from a lowtemperature phase (martensite) to a high-temperature phase (austenite) by thermoelastic conversion, it can return to its original state under the influence of the heating process. This behavior is called the shape memory effect [26]. Figure 1 depicts a stress-strain-temperature diagram that determines the SME mechanism. The austenite is phase transformed to the martensite phase under the effect of the stress and cooling process; firstly, the austenite phase transforms into twinned-martensite $(1 \rightarrow 2)$, and then its

\footnotetext{
* Corresponding author.

E-mail address: safar87physics@gmail.com (S. Mohammed)
}

Received 25 June 2021; Received in revised form 15 Semptember 2021; Accepted 27 Semptember 2021 
crystal structure changes to detwinned-martensite $(2 \rightarrow 3)$. When the effect of mechanical stress is removed through the $(3 \rightarrow 4)$ process, its crystal structure stays constant, but under the effect of the heating process, the alloy can recover to its parent phase (austenite) through $(4 \rightarrow 1)$ [26].

Based on the SME, two different types of SMAs have been classified: one-way shape memory alloy (OWSMA) and two-way shape memory alloy (TWSMA). In OWSMA, the alloy can remember only one predetermined shape given in the austenite phase, while in TWSMA, the alloy can be trained to remember two different shapes in two various temperatures. Generally, OWSMAs have more commercial applications compared to TWSMAs [27].

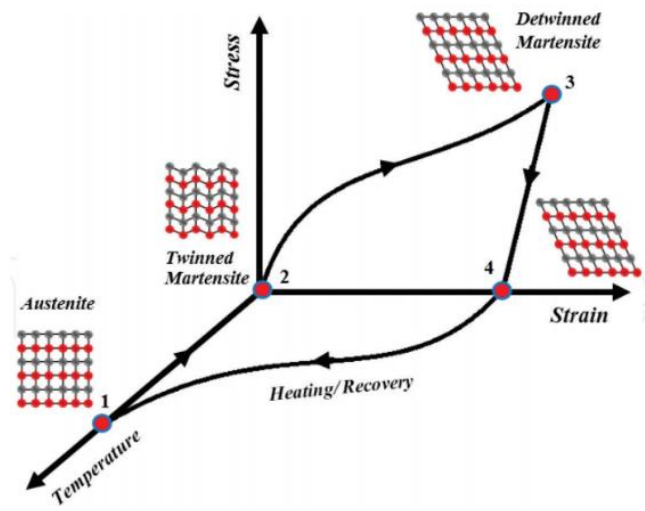

Figure 1. Schematic diagram of SME [26]

\subsection{Super Elasticity (SE)}

SE is another unique property of SMAs, which has more technological applications. SE does not need temperature change [28], but in a specific temperature between austenite finish and martensite deformation, the superelasticity can be obtained from an SMA [28]. Figure 2 shows the superelasticity mechanism in a stress-strain diagram. After the applying stress exceeds elastic $(A \rightarrow B)$ deformation, a martensite phase transformation takes place $(\mathrm{B} \rightarrow \mathrm{C})$. After austenite is compactly transformed to the martensite phase, the crystal structure of the alloy changes from cubic to a detwinned martensite crystal structure. The stress is stored as elastic energy so after removing the external load, the restoring energy returns the deformed alloy to its original shape, however, by over-stressing the alloy, a slip can happen that leads to permanent deformation.

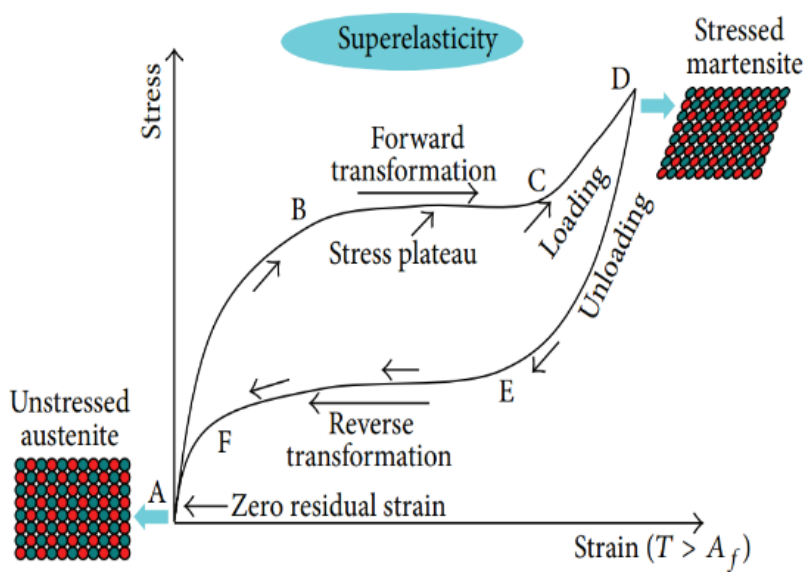

Figure 2. Schematic diagram of the SE [28]

\section{$3 \quad$ Biocompatible Properties}

In this chapter, the main well-known biocompatible properties of materials, especially NiTi-based alloys were discussed. Table 1 lists the biocompatibility of some elements, includes $\mathrm{Ni}$ and $\mathrm{Ti}$.

\subsection{Carcinogenic}

Carcinogenic is one of the most imperfections or harmful properties that must be taken into account for the substances which are used in medical treatments and manufacturing medical devices that are implanted into the human body [29]. Also, carcinogenic can increases cancer [30]. Chemical carcinogenic which refers to some chemical substances such as arsenic (As), cadmium (Cd), nickel (Ni), and selenium (Se), can destroy DNA that directly or indirectly causes a mutation in the essential oncogene or immune cell gene that causes cancer [31]. The NiTi-based shape memory alloys are the most popular ones that are used in biomedical applications, however, one of the big problems of using NiTi as a biomaterial is the release of the carcinogenic $\mathrm{Ni}$ and $\mathrm{Ti}$ ions into the human body [32]. There are more works in the literature where they were treated this problem by surface modifications and coating methods to improve the corrosion resistance by reduced the carcinogenicity of Ni-Ti alloy [33-36].

O'Brien et al. carried out the passivation process on a NiTi SMA; they treated samples thermally and then they passivated them in a nitric acid solution. They stated that the biocompatibility of the NiTi alloy was improved. The surface analysis indicated that after the passivation process $\mathrm{Ni}$ and $\mathrm{NiO}$ content were reduced and $\mathrm{TiO}_{2}$ increased on the surface. Also, they concluded that the corrosion resistance of the alloy was proportional to the quantity of nickel removed [37]. Likewise, El Abedin and coworkers improved the biocompatibility of a NiTi alloy by reducing the carcinogenic Ni content. They coated the NiTi SMA with a thin layer of Ta using a $3.5 \% \mathrm{NaCl}$ solution; they stated that the corrosion resistance was improved after coating the alloy [32].

\subsection{Genotoxic}

Genotoxic is one of the properties of chemical elements that are concerning in biomedical applications to avoid cancer due to the change in the genetic information of the organs and mutation by damaging the DNA of the cells [38]. The indirect and direct DNA damage, due to genotoxicity includes induction of a mutation, and direct DNA damage, resulting in mutations. It induces immediate and inherited modifications which can be transmitted to subsequent cell generations [39]. It is known that NiTibased alloys have several important and interesting properties such as superelasticity, shape memory, and high damping property, however, due to the presence of $\mathrm{Ni}$ element, the NiTi-based alloys are listed in genotoxic materials [38]. Assad et al. decreased the genotoxicity for a NiTi SMA by diminishing the amount of Nickel in a NiTi alloy. They found that the genotoxicity of pure Titanium is smaller than a binary NiTi, stainless steel, and pure nickel. Based on genotoxicity results, they sorted the materials as $\mathrm{Ti}<\mathrm{Ni}-\mathrm{Ti}<$ stainless steel $<\mathrm{Ni}[40]$. 


\subsection{Cytotoxicity}

Cytotoxicity is one of the important properties of chemical elements or materials that causes cell damage or cell death when a cytotoxic material is implanted inside a human body. The prefix (cyto) means cell, and (toxic) means poison. Chemotherapy is used for treating the damage to cancer cells caused by cytotoxic material [41]. Cytotoxicity testing is so important for the biomedical element used for implanting applications [42]. NiTi-based shape memory alloys are one of the biomedical materials that are also cytotoxicity because nickel is one of the toxic chemical elements. However, this issue can be treated by diminishing $\mathrm{Ni}$ or substituting $\mathrm{Ni}$ with a third biocompatible element. Tabish, et al. added Fe as the third element into a NiTi alloy with composition of $\mathrm{Ti}_{50} \mathrm{Ni}_{48} \mathrm{Fe}_{2}, \quad \mathrm{Ti}_{50} \mathrm{Ni}_{47} \mathrm{Fe}_{3}$, and $\mathrm{Ti}_{50} \mathrm{Ni}_{45} \mathrm{Fe}_{5}$, They implanted the samples inside the rabbit body, and they tested the blood and histology of various vital organs of the rabbit after 4,8 , and 12 weeks. Thus, they stated that the ternary NiTiFe alloys showed no sign of cytotoxicity and the alloys were passive and had no reaction with the living organs inside the rabbit body [43].

\subsection{Mutagenic}

Mutagenic is another property of materials that can cause a permanent change in the genetic code of a host cell $[44,45]$. The permanent change in the amount or structure of the genetic code and chromosome of the organism is called mutation [46]. Normally, the human body has enough immunity to these mutations and it can recognize and repair some of the mutations, however, some of these mutations are not repaired and not recognized by the immunity system, therefore, they may produce a tumor and develop cancer [47]. Although, as aforementioned, a NiTi SMA has high biocompatibility, Nickel as a main constituent of the alloy is listed in mutagen elements that should be taken into account [48].

\subsection{Allergic}

An allergy is an immune system reaction to a foreign material that is not normally dangerous to the body. These materials are called allergens, and allergic reactions can be produced when these materials enter a body. These materials have many types such as pollen, foods, and pet dander [49, 50]. Sometimes, a NiTi shape memory alloy can also classify as an allergen material because $\mathrm{Ni}$ is one of the five elements (Amalgam, Gold, Nickel, Chromate, and Platinum) that are caused to allergic, and it ranks third among this list [51]. Also, generally, females have more sensitivity to Nickel than males. Somehow, up to $20 \%$ of females have sensitivity to nickel, while, only $1-2 \%$ of males are sensitive to this element [52-54]. This allergy can be treated by release the amount of Nickel in the alloy or by surface coating to avoid Ni-leakage [55]. Kim, et al. coated a NiTi alloy with both nitride and epoxy and they subjected the samples in dissolution with $0.9 \% \mathrm{NaCl}$ and neutral $\mathrm{PH}$ at room temperature. The result showed that nitride has no significant effect on decreasing the allergy of the NiTi because it did not affect the corrosion of the alloy, while, they stated that epoxy decreased the allergy of the NiTi alloy because the epoxy increased the corrosion resistance of the alloy [56].

\subsection{Prone to Corrosion}

Despite implanting materials have more benefits in biomedical applications, they sometimes have side effects and cause additional health issues [57]. One of these side effects is corrosion which is the degradation of the implanting materials by an electrochemical attack when they are placed inside the host body. The implanted materials normally face various electrolyte environments, such as blood, water, chlorine, sodium, plasma, and amino acids, therefore, these fluids may cause corrode the implanted metals [58]. NiTi SMAs have comparably good corrosion resistance, but, they can be further improved by some different techniques. Jean et al. added $\mathrm{Cu}$ into $\mathrm{Ni}-\mathrm{Ti}$ alloy, and they reported that the corrosion rate of the equiatomic NiTi is greater than the ternary $\mathrm{NiTiCu}$ alloy [59]. Likewise, Ruiz, et al. investigated the effect of both boron addition and heat treatment on the corrosion resistance of a NiTi alloy. They added 250, 500, and 1000 ppm of B into Ni55-Ti45, at the same time, and they performed heat treatment on the samples at $900{ }^{\circ} \mathrm{C}$ for 4 hours. Their results showed that after adding 250 and 500 ppm of $\mathrm{B}$, the corrosion rate was decreased but $1000 \mathrm{ppm}$ B increased the corrosivity of the alloy [60]. Also, Iijima, et al. performed a surface configuration method on a NiTi alloy. They polished the surface alloy with $0.9 \% \mathrm{NaCl}$ and $1 \%$ lactic acid solutions, and they found that a thick oxide layer $\mathrm{TiO} 2$ was formed on the Ni-Ti surface by the heat treatment and subsequent pickling processes. Besides, they realized that this oxide layer improved both general and localized corrosion of the NiTi in [61].

Also, the corrosion resistance of a NiTi alloy can be improved by a chemical treatment method, which is called passivation. Passivation can be defined as the anticorrosion mechanism or it is a loss of electrochemical activity, whereby the passive layer is produced as a barrier between the surface of the metal and the electrolyte, therefore this protection layer can increase the corrosion resistance of the material [62-67].

\section{Conclusions}

Since NiTi-based shape memory alloys (SMAs) are not a passive material, they widely are investigated from various biocompatible perspectives. In this review, the essential physical properties of the NiTi alloys were discussed. Additionally, the well-known biocompatible terms including carcinogenic, genotoxic, cytotoxicity, mutagenic, allergic, and corrosivity were clarified for NiTi alloys. Some significant studies that investigated the biocompatibility of NiTi-based SMAs and the various strategies used to improve the alloy and reduce the risk of Ni-leakages were reviewed. Researchers could achieve good results, however, there are still many issues that need more studies. 
Table 1. The biocompatibility of some elements [29]

\begin{tabular}{|c|c|c|c|c|c|c|c|c|c|}
\hline $\begin{array}{l}\text { Periodic } \\
\text { position }\end{array}$ & Element & Biocompatible & Carcinogenic & Genotoxic & Mutagenic & Cytotoxic & Allergenic & $\begin{array}{c}\text { Pron to } \\
\text { corrosion }\end{array}$ & Other \\
\hline \multirow{8}{*}{$3 d$} & $\mathrm{Ti}$ & $\checkmark$ & $\mathrm{x}$ & $\mathrm{X}$ & $\mathrm{X}$ & Med & $\mathrm{x}$ & $\mathrm{X}$ & $\mathrm{X}$ \\
\hline & $\mathrm{V}$ & $\mathrm{X}$ & $\checkmark$ & $\checkmark$ & $\checkmark$ & High & Disputed & $\mathrm{x}$ & $\mathrm{X}$ \\
\hline & $\mathrm{Cr}$ & $\mathrm{X}$ & Disputed & $\checkmark$ & $\mathrm{X}$ & High & $\checkmark$ & $\mathrm{X}$ & $\mathrm{X}$ \\
\hline & $\mathrm{Mn}$ & $\mathrm{X}$ & X & $\checkmark$ & $\mathrm{X}$ & High & $\mathrm{X}$ & $\checkmark$ & $\mathrm{X}$ \\
\hline & $\mathrm{Fe}$ & $\mathrm{x}$ & $\mathrm{X}$ & $\checkmark$ & $\mathrm{x}$ & Med & $\mathrm{X}$ & $\checkmark$ & $\mathrm{X}$ \\
\hline & $\mathrm{Co}$ & $\mathrm{X}$ & $\checkmark$ & $\checkmark$ & $\checkmark$ & High & $\checkmark$ & $\checkmark$ & $\checkmark$ \\
\hline & $\mathrm{Ni}$ & $\mathrm{X}$ & $\checkmark$ & $\checkmark$ & $\checkmark$ & High & $\checkmark$ & $\checkmark$ & $\checkmark$ \\
\hline & $\mathrm{Cu}$ & $\mathrm{X}$ & $\mathrm{X}$ & $\checkmark$ & $\checkmark$ & High & $\checkmark$ & $\checkmark$ & $\checkmark$ \\
\hline \multirow{8}{*}{$4 d$} & $\mathrm{Zr}$ & $\checkmark$ & $\mathrm{X}$ & $\mathrm{X}$ & $\mathrm{X}$ & Low & $\mathrm{X}$ & $\mathrm{X}$ & $\mathrm{X}$ \\
\hline & $\mathrm{Nb}$ & $\checkmark$ & $\mathrm{X}$ & $\mathrm{x}$ & $\mathrm{x}$ & Low & $\mathrm{x}$ & $\mathrm{x}$ & $\mathrm{x}$ \\
\hline & Mo & $\mathrm{X}$ & Disputed & $\checkmark$ & $\checkmark$ & Low & $\checkmark$ & $\checkmark$ & $\checkmark$ \\
\hline & $\mathrm{Tc}$ & $\mathrm{x}$ & \multicolumn{7}{|c|}{-radioactive- } \\
\hline & $\mathrm{Ru}$ & $\mathrm{X}$ & $\mathrm{X}$ & $\mathrm{X}$ & $\mathrm{X}$ & Med & $\mathrm{X}$ & $\mathrm{X}$ & $\checkmark$ \\
\hline & $\mathrm{Rh}$ & $\mathrm{x}$ & $\checkmark$ & $\checkmark$ & $\checkmark$ & High & Unknown & $\mathrm{x}$ & $\mathrm{X}$ \\
\hline & $\mathrm{Pd}$ & $\mathrm{X}$ & $\checkmark$ & $\mathrm{X}$ & Disputed & Med & $\checkmark$ & $\mathrm{X}$ & $\mathrm{x}$ \\
\hline & $\mathrm{Ag}$ & $\mathrm{X}$ & $\mathrm{X}$ & $\mathrm{X}$ & X & High & $\checkmark$ & $\mathrm{X}$ & $\checkmark$ \\
\hline \multirow{8}{*}{$5 d$} & $\mathrm{Hf}$ & Unknown & Unknown & Unknown & Unknown & Med & $\mathrm{x}$ & $\mathrm{x}$ & Unknown \\
\hline & $\mathrm{Ta}$ & $\checkmark$ & X & $\mathrm{X}$ & $\mathrm{X}$ & Low & $\mathrm{X}$ & $\mathrm{X}$ & X \\
\hline & $\mathrm{W}$ & X & $\checkmark$ & $\checkmark$ & X & Med & $\mathrm{X}$ & $\checkmark$ & X \\
\hline & $\operatorname{Re}$ & Unknown & Unknown & Unknown & Unknown & Unknown & $\mathrm{X}$ & $\mathrm{X}$ & Unknown \\
\hline & Os & $\mathrm{X}$ & Unknown & $\checkmark$ & $\checkmark$ & High & $\mathrm{x}$ & $\checkmark$ & $\mathrm{X}$ \\
\hline & $\mathrm{Ir}$ & $\mathrm{X}$ & X & $\mathrm{X}$ & $\checkmark$ & High & $\mathrm{X}$ & $\mathrm{X}$ & $\checkmark$ \\
\hline & $\mathrm{Pt}$ & $\mathrm{X}$ & $\checkmark$ & $\checkmark$ & $\checkmark$ & High & $\checkmark$ & $\mathrm{X}$ & $\mathrm{X}$ \\
\hline & $\mathrm{Au}$ & $\checkmark$ & $\mathrm{X}$ & $\mathrm{X}$ & $\mathrm{X}$ & High & $\mathrm{X}$ & $\mathrm{X}$ & $\mathrm{X}$ \\
\hline \multirow{3}{*}{ Other } & $\mathrm{Al}$ & $\mathrm{X}$ & $\mathrm{X}$ & $\checkmark$ & $\mathrm{X}$ & Low & $\mathrm{X}$ & $\mathrm{X}$ & $\checkmark$ \\
\hline & $\mathrm{Zn}$ & $\mathrm{X}$ & $\mathrm{X}$ & $\mathrm{X}$ & $\mathrm{X}$ & High & $\mathrm{X}$ & $\mathrm{X}$ & $\checkmark$ \\
\hline & $\mathrm{Sn}$ & $\checkmark$ & $\mathrm{X}$ & $\mathrm{X}$ & $\mathrm{X}$ & Low & $\mathrm{X}$ & $\mathrm{X}$ & $\checkmark$ \\
\hline
\end{tabular}

\section{Declaration}

The authors declare that the ethics committee approval is not required for this study.

\section{References}

[1] Qader, I.N., Kök, M., Dağdelen, F., \& Aydogdu, Y. (2019). A Review of Smart Materials: Researches and Applications, El-Cezerî Journal of Science and Engineering, C 6, 755-788.

[2] Lobo, P.S., Almeida, J., \& Guerreiro, L. (2015). Shape memory alloys behaviour: a review, Procedia Engineering, C 114, 776-783.

[3] Kök, M., Qader, I.N., Mohammed, S.S., Öner, E., Dağdelen, F., \& Aydogdu, Y. (2019). Thermal stability and some thermodynamics analysis of heat treated quaternary CuAlNiTa shape memory alloy, Materials Research Express, C 7, 015702

[4] Mohammed, S.S., Mediha, K., Qader, I.N., \& Dağdelen, F. (2019). The Developments of piezoelectric Materials and Shape Memory Alloys in Robotic Actuator Systems, Avrupa Bilim ve Teknoloji Dergisi, C, 1014-1030.

[5] Mohammed, S.S., Kok, M., Qader, I.N., Kanca, M.S., Ercan, E., Dağdelen, F., \& Aydoğdu, Y. (2020). Influence of Ta Additive into Cu84-xAl13Ni3 (wt\%) Shape Memory Alloy Produced by Induction Melting, Iranian Journal of Science and Technology, Transactions A: Science, C 44, 1167-1175.

[6] Dagdelen, F., Balci, E., Qader, I.N., Ozen, E., Kok, M., Kanca, M.S., Abdullah, S.S., \& Mohammed, S.S. (2020). Influence of the $\mathrm{Nb}$ Content on the Microstructure and Phase Transformation Properties of NiTiNb Shape Memory Alloys, JOM, C 72, 1664-1672.
[7] Qader, I.N., Öner, E., Kok, M., Mohammed, S.S., Dağdelen, F., Kanca, M.S., \& Aydoğdu, Y. (2020). Mechanical and Thermal Behavior of Cu84-xAl13Ni3Hfx Shape Memory Alloys, Iranian Journal of Science and Technology, Transactions A: Science, C.

[8] Tatar, C., Acar, R., \& Qader, I.N. (2020). Investigation of thermodynamic and microstructural characteristics of $\mathrm{NiTiCu}$ shape memory alloys produced by arc-melting method, The European Physical Journal Plus, C 135, 311.

[9] Qader, I.N., Mediha, K., Dağdelen, F., \& Abdullah, S.S. (2020). The Effect of Different Parameters on Shape Memory Alloys, Sakarya Üniversitesi Fen Bilimleri Enstitüsü Dergisi, C 24, 881-902.

[10] Qader, I.N., Kok, M., \& Cirak, Z.D. (2020). The effects of substituting $\mathrm{Sn}$ for $\mathrm{Ni}$ on the thermal and some other characteristics of NiTiSn shape memory alloys, Journal of Thermal Analysis and Calorimetry, C.

[11] Qader, I.N., Ercan, E., Faraj, B.A.M., Kok, M., Dagdelen, F., \& Aydogdu, Y. (2020). The Influence of Time-Dependent Aging Process on the Thermodynamic Parameters and Microstructures of Quaternary Cu79-Al12-Ni4-Nb5 (wt\%) Shape Memory Alloy, Iranian Journal of Science and Technology, Transactions A: Science, C 44, 903-910.

[12] Mohammed, S.S., Kök, M., Çirak, Z.D., Qader, I.N., Dağdelen, F., \& Zardawi, H.S.A. (2020). The Relationship between Cobalt Amount and Oxidation Parameters in NiTiCo Shape Memory Alloys, Physics of Metals and Metallography, C 121, 1411-1417.

[13] Balci, E., Dagdelen, F., Qader, I.N., \& Kok, M. (2021). Effects of substituting $\mathrm{Nb}$ with $\mathrm{V}$ on thermal analysis and biocompatibility assessment of quaternary NiTiNbV SMA, The European Physical Journal Plus, C 136, 145. 
[14] Buytoz, S., Dagdelen, F., Qader, I.N., Kok, M., \& Tanyildizi, B. (2019). Microstructure Analysis and Thermal Characteristics of NiTiHf Shape Memory Alloy with Different Composition, Metals and Materials International, C.

[15] Dagdelen, F., Aldalawi, M.A.K., Kok, M., \& Qader, I.N. (2019). Influence of $\mathrm{Ni}$ addition and heat treatment on phase transformation temperatures and microstructures of a ternary CuAlCr alloy, The European Physical Journal Plus, C 134, 66.

[16] Kök, M., Al-Jaf, A.O.A., Çirak, Z.D., Qader, I.N., \& Özen, E. (2020). Effects of heat treatment temperatures on phase transformation, thermodynamical parameters, crystal microstructure, and electrical resistivity of NiTiV shape memory alloy, Journal of Thermal Analysis and Calorimetry, C 139, 3405-3413.

[17] Ercan, E., Dagdelen, F., \& Qader, I.N. (2020). Effect of tantalum contents on transformation temperatures, thermal behaviors and microstructure of CuAlTa HTSMAs, Journal of Thermal Analysis and Calorimetry, C 139, 29-36.

[18] Dagdelen, F., Kok, M., \& Qader, I.N. (2019). Effects of Ta Content on Thermodynamic Properties and Transformation Temperatures of Shape Memory NiTi Alloy, Metals and Materials International, C 25, 1420-1427.

[19] Kök, M., Zardawi, H.S.A., Qader, I.N., \& Sait Kanca, M. (2019). The effects of cobalt elements addition on Ti2Ni phases, thermodynamics parameters, crystal structure and transformation temperature of $\mathrm{NiTi}$ shape memory alloys, The European Physical Journal Plus, C 134, 197.

[20] Acar, E., Kok, M., \& Qader, I.N. (2020). Exploring surface oxidation behavior of NiTi-V alloys, The European Physical Journal Plus, C 135, 58.

[21] Qader, I.N., Kök, M., \& Dağdelen, F. (2019). Effect of heat treatment on thermodynamics parameters, crystal and microstructure of (Cu-Al-Ni-Hf) shape memory alloy, Physica B: Condensed Matter, C 553, 1-5.

[22] Zafar, M.S., Ullah, R., Qamar, Z., Fareed, M.A., Amin, F., Khurshid, Z., \& Sefat, F., 2 - Properties of dental biomaterials, in Advanced Dental Biomaterials, Z. Khurshid, S. Najeeb, M.S. Zafar, and F. Sefat, Editors. 2019, Woodhead Publishing. p. 7-35.

[23] Jin, S., Zhang, Y., Wang, Q., Zhang, D., \& Zhang, S. (2013). Influence of TiN coating on the biocompatibility of medical NiTi alloy, Colloids and Surfaces B: Biointerfaces, C 101, 343-349.

[24] Zhang, L., Duan, Y., Gao, Z., Ma, J., Liu, R., Liu, S., Tu, Z., Liu, Y., Bai, C., Cui, L., Yang, F., Liu, J., Kong, J., \& Li, Y. (2017). Graphene enhanced anti-corrosion and biocompatibility of NiTi alloy, NanoImpact, C 7, 7-14.

[25] Tao, H., Chu, C.-1., Yin, L.-h., Pu, Y.-p., Dong, Y.-s., Chao, G., Sheng, X.-b., Chung, J.-C., \& Chu, P.-K. (2007). In vitro biocompatibility of titanium-nickel alloy with titanium oxide film by $\mathrm{H} 2 \mathrm{O} 2$ oxidation, Transactions of Nonferrous Metals Society of China, C 17, 553-557.

[26] Lagoudas, D.C., (2008). Shape memory alloys: modeling and engineering applications, Springer,

[27] Jani, J.M., Leary, M., Subic, A., \& Gibson, M.A. (2014). A review of shape memory alloy research, applications and opportunities, Materials \& Design (1980-2015), C 56, 10781113.

[28] Hu, J.W. \& Noh, M.-H. (2015). Seismic response and evaluation of SDOF self-centering friction damping braces subjected to several earthquake ground motions, Advances in Materials Science and Engineering, C 2015.

[29] Hayes, R.B. (1997). The carcinogenicity of metals in humans, Cancer Causes \& Control, C 8, 371-385.

[30] Hayashi, Y. (1992). Overview of genotoxic carcinogens and non-genotoxic carcinogens, Experimental and Toxicologic Pathology, C 44, 465-471.
[31] Das, S., Kundu, M., Jena, B.C., \& Mandal, M., Chapter 25 Causes of cancer: physical, chemical, biological carcinogens, and viruses, in Biomaterials for 3D Tumor Modeling, S.C. Kundu and R.L. Reis, Editors. 2020, Elsevier. p. 607-641.

[32] El Abedin, S.Z., Welz-Biermann, U., \& Endres, F. (2005). A study on the electrodeposition of tantalum on NiTi alloy in an ionic liquid and corrosion behaviour of the coated alloy, Electrochemistry communications, C 7, 941-946.

[33] YAN, X.-j., YANG, D.-z., \& LIU, X.-p. (2006). Electrochemical behavior of YAG laser-welded NiTi shape memory alloy, Transactions of Nonferrous Metals Society of China, C 16, 572-576.

[34] Villermaux, F., Tabrizian, M., L'H, Y., Meunier, M., \& Piron, D. (1997). Excimer laser treatment of NiTi shape memory alloy biomaterials, Applied surface science, C 109, 62-66.

[35] Tan, L., Dodd, R., \& Crone, W. (2003). Corrosion and wearcorrosion behavior of NiTi modified by plasma source ion implantation, Biomaterials, C 24, 3931-3939.

[36] Sun, F., Sask, K., Brash, J., \& Zhitomirsky, I. (2008). Surface modifications of Nitinol for biomedical applications, Colloids and Surfaces B: Biointerfaces, C 67, 132-139.

[37] O'Brien, B., Carroll, W., \& Kelly, M. (2002). Passivation of nitinol wire for vascular implants - a demonstration of the benefits, Biomaterials, C 23, 1739-1748.

[38] Kurelec, B. (1993). The genotoxic disease syndrome, Marine Environmental Research, C 35, 341-348.

[39] Martin-Camean, A., Jos, A., Mellado-Garcia, P., IglesiasLinares, A., Solano, E., \& Camean, A.M. (2015). In vitro and in vivo evidence of the cytotoxic and genotoxic effects of metal ions released by orthodontic appliances: A review, Environmental toxicology and pharmacology, C 40, 86-113.

[40] Assad, M., Lemieux, N., Rivard, C., \& Yahia, L.H. (1999). Comparative in vitro biocompatibility of nickel-titanium, pure nickel, pure titanium, and stainless steel: genotoxicity and atomic absorption evaluation, Bio-medical materials and engineering, C 9, 1-12.

[41] Andersen, M.H., Schrama, D., thor Straten, P., \& Becker, J.C. (2006). Cytotoxic T cells, Journal of Investigative Dermatology, C 126, 32-41.

[42] Riss, T.L., Moravec, R.A., \& Niles, A.L., Cytotoxicity Testing: Measuring Viable Cells, Dead Cells, and Detecting Mechanism of Cell Death, in Mammalian Cell Viability: Methods and Protocols, M.J. Stoddart, Editor 2011, Humana Press: Totowa, NJ. p. 103-114.

[43] Tabish, T., Butt, T., Ali, M., Ali, M., Shaikh, R., Atiq, S., \& Draghi, L. (2014). In vivo cytotoxic evaluation of Ti-Ni-Fe shape memory alloys, Materials Technology, C 29, 139-143.

[44] Ariza, M.E. \& Williams, M.V. (1996). Mutagenesis of AS52 cells by low concentrations of lead (II) and mercury (II), Environmental and molecular mutagenesis, C 27, 30-33.

[45] Singer, B. \& Grunberger, D., (2012). Molecular biology of mutagens and carcinogens, Springer Science \& Business Media,

[46] Adler, I.D. (2000). Spermatogenesis and mutagenicity of environmental hazards: extrapolation of genetic risk from mouse to man, Andrologia, C 32, 233-237.

[47] Joshi, N., Ravindran, A., \& Mahajan, V. (2011). Investigations on chemical mutagen sensitivity in onion (Allium cepa L.), International Journal of Botany, C 7, 243248.

[48] Christie, N.T. \& Tummolo, D.M. (1989). The effect of Ni (II) on DNA replication, Biological trace element research, $\mathrm{C} 21$, 3-12.

[49] Campbell, A., Michel, F.-B., Bremard-Oury, C., Crampette, L., \& Bousquet, J. (1996). Overview of allergic mechanisms, Drugs, C 52, 15-19.

[50] Wiltshire, W.A., Ferreira, M.R., \& Ligthelm, A.J. (1996). Allergies to dental materials, Quintessence InternationalEnglish Edition, C 27, 513-520. 
[51] Baer, H. (1983). Allergic contact dermatitis from plants, Handbook of Natural Toxins: Plant and Fungal Toxins, C 1, 421-442.

[52] Burrows, D. (1986). Hypersensitivity to mercury, nickel and chromium in relation to dental materials, International dental journal, C 36, 30-34.

[53] Jones, T.K., Hansen, C.A., Singer, M.T., \& Kessler, H.P. (1986). Dental implications of nickel hypersensitivity, The Journal of prosthetic dentistry, C 56, 507-509.

[54] Al-Waheidi, E. (1995). Allergic reaction to nickel orthodontic wires: a case report, Quintessence International, C 26.

[55] Rahilly, G. \& Price, N. (2003). Nickel allergy and orthodontics, Journal of orthodontics, C 30, 171-174.

[56] Kim, H. \& Johnson, J.W. (1999). Corrosion of stainless steel, nickel-titanium, coated nickel-titanium, and titanium orthodontic wires, The Angle Orthodontist, C 69, 39-44.

[57] Novikova, G. (2011). Introduction to corrosion of bioimplants, Protection of Metals and Physical Chemistry of Surfaces, C 47, 372-380.

[58] Manivasagam, G., Dhinasekaran, D., \& Rajamanickam, A. (2010). Biomedical implants: corrosion and its prevention-a review, Recent patents on corrosion science, $\mathrm{C}$.

[59] Jean, R.-D. \& Duh, J.-B. (1995). The thermal cycling effect on Ti-Ni-Cu shape memory alloy, Scripta metallurgica et materialia, C 32.

[60] Ruiz, J., Rosales, I., Gonzalez-Rodriguez, J., \& Uruchurtu, J. (2010). Effect of B on the corrosion resistance of a Ni-Ti alloy in simulated human body solution, International Journal of Electrochemical Science, C 5, 593-604.
[61] Iijima, M., Endo, K., Ohno, H., Yonekura, Y., \& Mizoguchi, I. (2001). Corrosion behavior and surface structure of orthodontic Ni-Ti alloy wires, Dental materials journal, C 20, 103-113.

[62] Yan, S., Song, G.-L., Li, Z., Wang, H., Zheng, D., Cao, F., Horynova, M., Dargusch, M.S., \& Zhou, L. (2018). A stateof-the-art review on passivation and biofouling of $\mathrm{Ti}$ and its alloys in marine environments, Journal of Materials Science \& Technology, C 34, 421-435.

[63] Dutta, R.S., Madangopal, K., Gadiyar, H.S., \& Banerjee, S. (1993). Biocompatibility of $\mathrm{Ni}-\mathrm{Ti}$ shape memory alloy, British Corrosion Journal, C 28, 217-221.

[64] Sato, N. \& Okamoto, G., Electrochemical passivation of metals, in Electrochemical Materials Science1981, Springer. p. 193-245.

[65] Simka, W., Kaczmarek, M., Baron-Wiecheć, A., Nawrat, G., Marciniak, J., \& Żak, J. (2010). Electropolishing and passivation of NiTi shape memory alloy, Electrochimica Acta, C 55, 2437-2441.

[66] Barison, S., Cattarin, S., Daolio, S., Musiani, M., \& Tuissi, A. (2004). Characterisation of surface oxidation of nickeltitanium alloy by ion-beam and electrochemical techniques, Electrochimica Acta, C 50, 11-18.

[67] Chu, C.L., Wang, R.M., Hu, T., Yin, L.H., Pu, Y.P., Lin, P.H., Wu, S.L., Chung, C.Y., Yeung, K.W.K., \& Chu, P.K. (2008). Surface structure and biomedical properties of chemically polished and electropolished NiTi shape memory alloys, Materials Science and Engineering: C, C 28, 14301434. 